\title{
Chemical Approach to Signal Transduction by Inositol Triphosphate
}

\section{Shoichiro Ozaki ${ }^{\star}$}

The Institute of Physical and Chemical Research, 2-1 Hirosawa, Wako, Saitama 351-0198, Japan

\begin{abstract}
Berridge discovered that inositol 1,4,5-trisphophate (IP3) was generated at the cell surface in response to cell stimulation and functioned as a second messenger to release $\mathrm{Ca}^{2+}$ from internal stores. Ozaki et al. succeeded in the first total synthesis of optically active IP $\mathrm{P}_{3}$ by 13 steps. He supported the signal transduction studies by supplying necessary reagents such as $\mathrm{IP}_{3}$, other IPx, phosphatidyl inositol, new synthetic methods and reagents. He discovered the regulators of $\mathrm{Ca}^{2+}$ release and consequent cellular processes.
\end{abstract}

Keywords: Signal transduction; Inositol trisphosphate; IP3Phosphatidyl inositol; Regulator of cellular process

\section{Introduction}

The fact that diacyl glycerol is second messenger was found by late Professor Yasutomi Nishizuka [1] and the fact that Inositol triphosphate $\left(\mathrm{IP}_{3}\right)$ is a second messenger was discovered by Michael Berridge who showed that it functioned to release $\mathrm{Ca}^{2+}$ from internal stores. This bifurcating signaling system is of fundamental importance in regulating a wide range of cellular process.

Signals (first messenger) like light, noise, taste, odor, hormone, neurotransmitter, drug attach to the plasma membrane where they are recognized by cell surface receptors. Upon binding of the ligand to the appropriate receptor, activation of $\mathrm{G}$ protein activates in turn phospholipase C. Active phospholipase C hydrolyzes phosphatidylinositol 4,5-bisphosphate $\left(\mathrm{PIP}_{2}\right)$ giving rise to two products: 1,2-diacylglycerol and inositol 1,4,5-triphosphate (IP ${ }_{3}$ ). $\mathrm{IP}_{3}$ stimulates the release of $\mathrm{Ca}^{2+}$ from the intracellular stores in the endoplasmic reticulum through $\mathrm{IP}_{3}$ receptor while regulating a wide range of cellular processes.<smiles>O=P(O)(O)OC1C(O)C(O)C(OP(=O)(O)O)C(OP(=O)(O)O)C1O</smiles>$$
\text { Inositol }
$$

\section{Why Plant Biosynthesize Inositol}

The rice bran, wheat, corn contain much phytic acid (inositol hexaphosphate) as Ca salt. Plant make glucose by photo synthesis from carbon dioxide and water. Some of glucose is converted to inositol. Inositol is converted to phospholipids ( $\mathrm{PIP}_{2}$ ) and phytic acid. PIP is converted to $\mathrm{IP}_{3}$ and diacylglycerol. These two compounds are essential for signal transduction of plant. Plant makes phytic acid as storage of phosphorous. Phosphorous is an essential atom as fertilizer because ii is an essential atom to make nucleic acid, DNA. The seed store phosphorous atom as a store so that even when seed germinate at no phosphorous land [1].

\section{Discovery of $\mathrm{IP}_{3}$}

Phospholipid was discovered by Bollow in 1961 [2] from bovine brain. The hypothesis of Michell [3] that the receptor controlled hydrolysis of phosphoinositides could be directly linked to cellular calcium mobilization. The observation by Berridge D-myo-inositol 1,4,5-trisphosphate $\left(\mathrm{IP}_{3}\right)$ act as a second messenger, a fundamental cell-signal transduction mechanism has been elucidated. $\mathrm{IP}_{3}$ stimulates the release of $\mathrm{Ca}^{2+}$ from the intracellular stores in the endoplasmic reticulum through $\mathrm{IP}_{3}$ receptor while regulating a wide range of cellular processes [4-25].

\section{Synthetic Competition of Inositol P}

The discovery of inositol phosphate in particular $\mathrm{IP}_{3}$ led to the dramatic stimulation for the synthesis of inositol phosphates. Many persons challenged the synthesis of inositol phosphate, starting from inositol, glucurolactone, phytic acid, arenas, quinic acid and L-quebrachitol.

A symposium; Inositol phosphates and Derivatives. Synthesis, biochemistry, and therapeutic potential was held by the division of carbohydrate Chemistry at the $200^{\text {th }}$ National meeting of the American Chemical Society, Washington DC, August 26-31.1990. ACS Symposium Series. 463 Edited by Allen B.Reitz was published.

The key problems in the synthesis of inositol phosphates are (1) synthesis and optical resolution of suitably protected inositol derivatives, (2) efficient phosphorylation of vicinal hydroxy groups.

In 1986, Ozaki et al succeeded in the first total synthesis of optically active myo-inositol tris $(1,4,5)$ phosphate from myo-inositol by 13 steps [26]. At this report, phosphorylation yield of 2,3,6-tribenzyl myoinositol by dianilidephophotyl chloride isolation yield was only $10 \%$. Then we have studied phosphorylation reagents and discovered new phsphorylation method Then we could get IP ${ }_{3}$ by best method in good

*Corresponding author: Shoichiro Ozaki, The Institute of Physical and Chemical Research, 2-1 Hirosawa, Wako, Saitama 351-0198, Japan, Tel/ Fax: 81-0467670991; E-mail: ozaki-0991@m.jcnnet.jp

Received September 15, 2014; Accepted September 24, 2014; Published October 04, 2014

Citation: Ozaki S (2014) Chemical Approach to Signal Transduction by Inositol Triphosphate. J Bioengineer \& Biomedical Sci 4: 133. doi: 10.4172/2155- 9538.1000133

Copyright: (C) 2014 Ozaki S. This is an open-access article distributed under the terms of the Creative Commons Attribution License, which permits unrestricted use, distribution, and reproduction in any medium, provided the original author and source are credited. 
Citation: Ozaki S (2014) Chemical Approach to Signal Transduction by Inositol Triphosphate. J Bioengineer \& Biomedical Sci 4: 133. doi: 10.4172/2155- 9538.1000133

yield as shown in Figure 1 [26,27].

This $\mathrm{IP}_{3}$ is produced by this method at DOJINDO (Kumamoto, Japan) and is distributed all over the world by the name of synthetic $\mathrm{IP}_{3}$.

The synthesis of $\mathrm{I}(1,4,5) \mathrm{P}_{3}$ are reported by many investigators Billington and Vacca (from myo-inositol orthoformate [28], Ballou, from myo-inisitol [29], Gigg [30], Ley from arenes using Pseudomonasoxidation [31], Falch from Quinic acid [32], Stepanov and Shvets [33], Prestwich prepared D-myo- $\left({ }^{3} \mathrm{H}\right) \mathrm{I}(1,4,5) \mathrm{P}_{3}$, essential and most used reagent for the study of signal transduction $[34,35]$ Phosphothioate analogur of $\mathrm{IP}_{3}$ by Potter [36].

\section{Different Source and Methods}

$\mathrm{IP}_{3}$ was obtained through 6 different sources:

- $\quad$ Starting from myo -inositol [26-32,35-38]

- $\quad$ Starting from L-quebrachitol ( natural rubber industry byproduct) [39-43]

- $\quad$ Siarting from arenes [33]

- $\quad$ Starting frm Quinic acid [34]

- $\quad$ Starting from D-glucuronolactone [42]

- Chemoenzymztic synthesis of D-myo-inositol 1,4,5trisphosphate [43-49]

\section{Methods to Get Optically Pure Compound by 5 Different Methods}

> Separation of diastereomers

- L- mentoxy acetyl chloride gave best result, because desired product was crystal [26]

> Starting from optically pure natural product

- $\quad$ From D-glucuronolactone [42], From Quinic acid [34]

- $\quad$ From L-quebrachitol [39-43]

, Use of tartaric acid ester [50]

, Use of enzyme (like Phosphorylase). Enzyme aided synthesis of D-myo-inositol 1,4,5-trisphosphate [43-48]

> Enzymic resolution of racemic 1,2:5,6-di-O-cyclohexylidene and 1,2:3,4-di-O-cyclohexylidene-myo-inositol [45]

> Enzymic resolution of sterically hindered myo-inositol derivatives [48]

> Enzyme aided regioselective acylation of nucleosides [49]

\section{Phosphorylation Reagents [51]}

- $\quad$ Tetrabenzyl pyrophosphate (TBPP) and n-BuLi [52].

TBPP

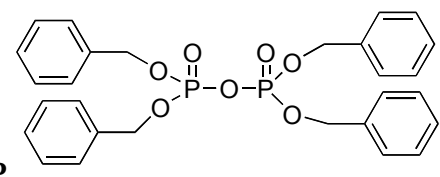

n-BuLi

- New phosphorylating reagent called OXDEP (o-xylylene N,Ndiethylphosphoamidite) $[53,54]$. By using this reagent, IP $_{3}$ and PIPx were obtained in good yield [27].

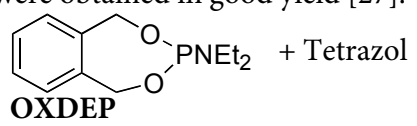

- $\quad$ DBPF Dibenzyl phosphorofluororidate $(\mathrm{BnO})_{2} \mathrm{P}(\mathrm{O}) \mathrm{F}$ [55]. This reagent was used for the synthesis of phosphofloridate analogues. Obtained phosphofloridates showed very interesting biological activity [56].<smiles>O=P1(O)OCc2ccccc2COP(=O)(F)c2ccccc2CO1</smiles>

[57]

- $\quad$ Step wise phosphorylation using $\mathrm{PCl}_{3}, \mathrm{BnOH}, \mathrm{C}_{6} \mathrm{H}_{5} \mathrm{COOOH}$

- Phosphorothioate synthesis based on the redox reaction of phosphite with tellurium (IV) chloride [58].

\section{Discovery of Phosphonium Salt Methodology}

This phosphonium salt methodology [59,60] provide a regioselective phospholylation. 1,2-Diol were phosphorylated regioselectively at C-1 with tribebzyl phosphite to give 1-dibenzyl phosphate 2-hyroxy free compound as shown in Figure 2. Other phosphory lating reagents do not have such selectivity. By using this free hydroxy group, we could get 2-acyl analog and IPx and PIPx. Three kind of combined reagents are possible. [59]

Trialkyl phosphite and pyridinium bromide perbromide method

(RO) $)_{3} \mathbf{P}+\mathrm{PyHBr}_{3}$

1H-Tetrazol catalyzed the reaction of trialkyl phosphite [61]

$(\mathrm{PO})_{3} \mathbf{P}+$ Tetrazole

Utilization of oxidizing character of $\mathrm{TeCl}_{4}$ [62]

(RO) $)_{3} \mathbf{P}+\mathrm{TeCl}_{4}$

The reaction of an alcohol with a trialkylphophite in the presence of pyridinuum bromide per bromide proceed via the phosphonium salt $(\mathrm{RO})_{3} \mathrm{P}^{+} \mathrm{Br}$ to afford the triester $\mathrm{R} 1-\mathrm{OP}(\mathrm{O})(\mathrm{OR})_{2}$, which can be converted to the phosphoric monoester by deprotection.

On the other hand, starting from dialkyl phosphoamidite (R0) ${ }_{2} \mathrm{PNR}$,'the corresponding triester product $\left(\mathrm{R}_{1} \mathrm{O}-\mathrm{R}_{2} \mathrm{O}-\mathrm{P}(\mathrm{O}) \mathrm{OR}\right.$ ") gave phosphoric mixed diesters.

The reactivity of phosphonium salt toward an alcohol seems to be between $\mathrm{P}^{\mathrm{III}}$ and $\mathrm{P}^{\mathrm{V}}$, therefore we expected that the phosphonium salt methodology would provide a regioselective phosphorylation method. 1,2-Diol was phosphorylated regioselectively.

Applying the phosphonium salt approach to the synthesis of phosphoinositides, the use of glyceryl phosphite, which was derived by the reaction of the glycerol derivatives with dimethylphosphoramidite in the presence of tetrazol, gave the protected $\mathrm{PI}(4,5) \mathrm{P} 2$.

We synthesized Phosphatidylinositol 3,4,5-trisphosphate [63,64], Unsaturated phosphatidyl inositol-3,4,5-trisphosphate [65], myoinositol 1.2,5,6-tetrakisphosphate [66], 4- $\alpha$-D-glucopyranosylmyo-inositol, enzymic transglycosylation product. [67], 2,6-DiO-(D-mannopyranosyl)phosphatidyl-D-myo-inositol [68], Phosphofluoridate analogs of myo-inositol 1,4,5-tris(phosphate) [56]. 


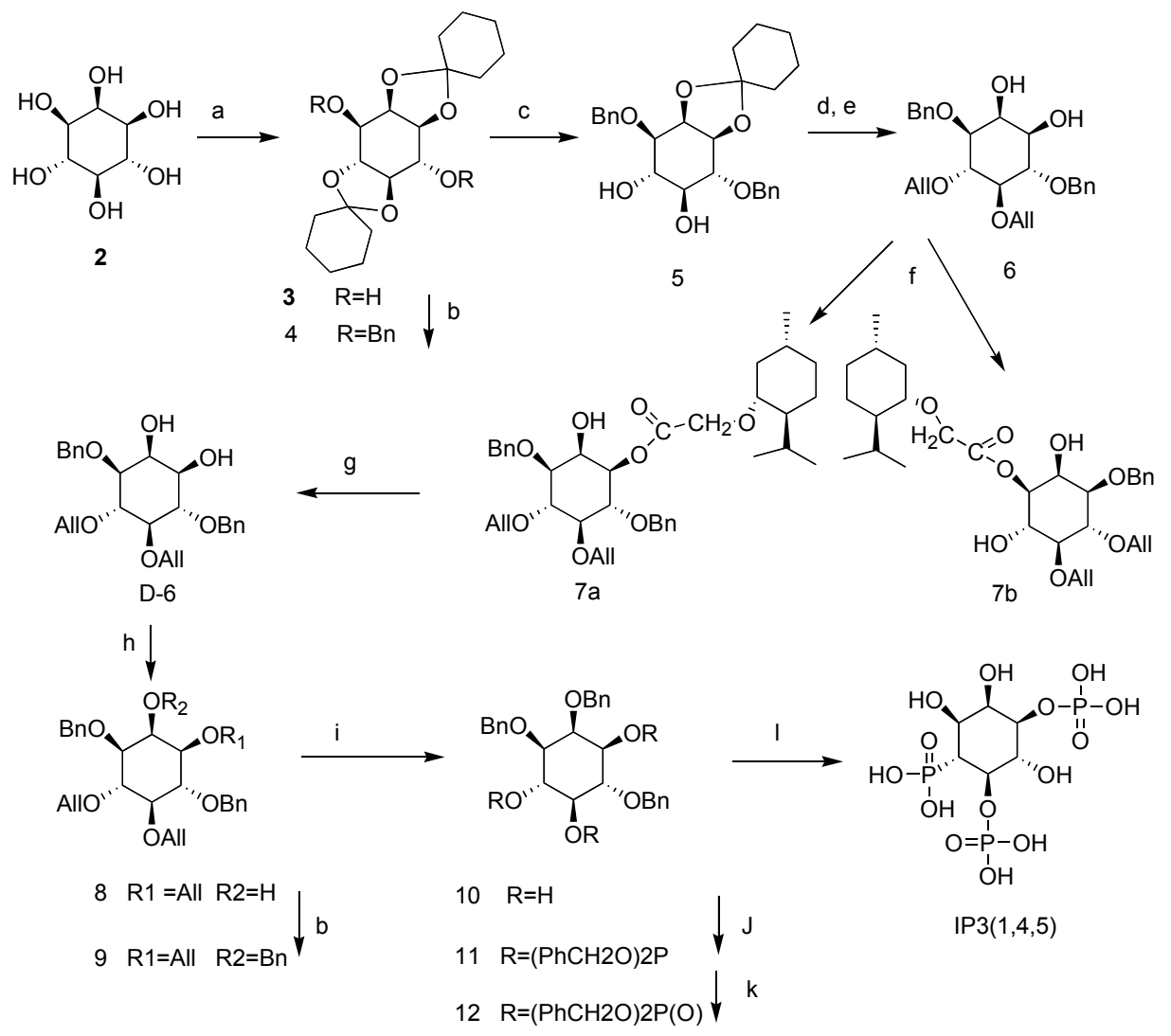

a:1-EtO-cyclohexane/TsOH, b:NaH/BnCl/DMF, c: $(\mathrm{HOCH} 2) 2 / \mathrm{TsOH}, . d: \mathrm{NaH} / \mathrm{AllBr} / \mathrm{DMF}$.

e :aq.AcOH, f: I-MentAcCl/Py, g: aq.NaOH/MeOH, h: AllBr/NaOH, i: RhCl(PPh3)3/DABCO thenHCl/MeOH

j: $(\mathrm{PhCH} 2 \mathrm{O}) 2 \mathrm{PN}(\mathrm{i}-\mathrm{Pr}) 2$. k: mCPBA, l: H2/5\% Pd-C

Figure 1: Synthesis of D-myo-inositol 1,4,5-trisphosphate

Finding of New Reaction, New Methods and New Reagents

\section{Finding of new protection methods}

- Protection by tetraisopropyldisiloxane-1,3-diyl group [69]

- Proximately assisted and chemoselectively cleavable protecting groups for alcohols, 2-[2-(arylmethyloxy)ethyl]benzoic esters [70].

\section{Finding of new deprotection methods}

- Deprotection of methyl group by $\mathrm{AlCl} 3-\mathrm{NaI}, \mathrm{AlCl} 3-\mathrm{Bu} 4 \mathrm{NI}$ [71]

- Deprotection of benzyl and allyl group by $\mathrm{AlCl} 3$-dimethyl aniline [72]

- Deprotection p-methoxybenzyl by trimethylsilylchloride-tin(II) chloride-anisole [73].

\section{Finding of diastereoselective addition methods}

Diastereoselective addition of organometallics to $\alpha$-keto esters [74].

\section{Finding of diastereoselective reduction methods}

Diastereoselective reduction of ketoester bearing chiro-inositol as chiral auxiliaries [75].

\section{Finding of novel deacylation Methods}

A Grignard reagent was used for deacylation without affecting the neighboring base-sensitive functional groups [76].

Finding of novel enatioselective acylation and deacylation Method $[38,77]$.

Enantioselective acylation and deacylation method using enzyme

\section{Finding of glycosidation method}

Glycosidation based on phosphite chemistry [78,79]

Phosphorylation of inositol 1,4,5-trisphosphate analogs by 3-kinase and dephosphorylation of inositol 1,3,4,5-tetrakisphosphate analogs by 5-phosphatase [80].

\section{Use of Inositol Derivatives as Chiral Auxialiaries}

- Diastereoselective addition of organometallics to keto esters [74].

- Asymmetric synthesis of tetrahydrofurans by diastereoselective $(3+2)$ cycloaddition of allylsilanes with ketoesters bearing optically active cyclitol as a chiral auxiliary [81].

- Preparation of optically active D 2-isooxazolines via addition 
Citation: Ozaki S (2014) Chemical Approach to Signal Transduction by Inositol Triphosphate. J Bioengineer \& Biomedical Sci 4: 133. doi: 10.4172/2155- 9538.1000133

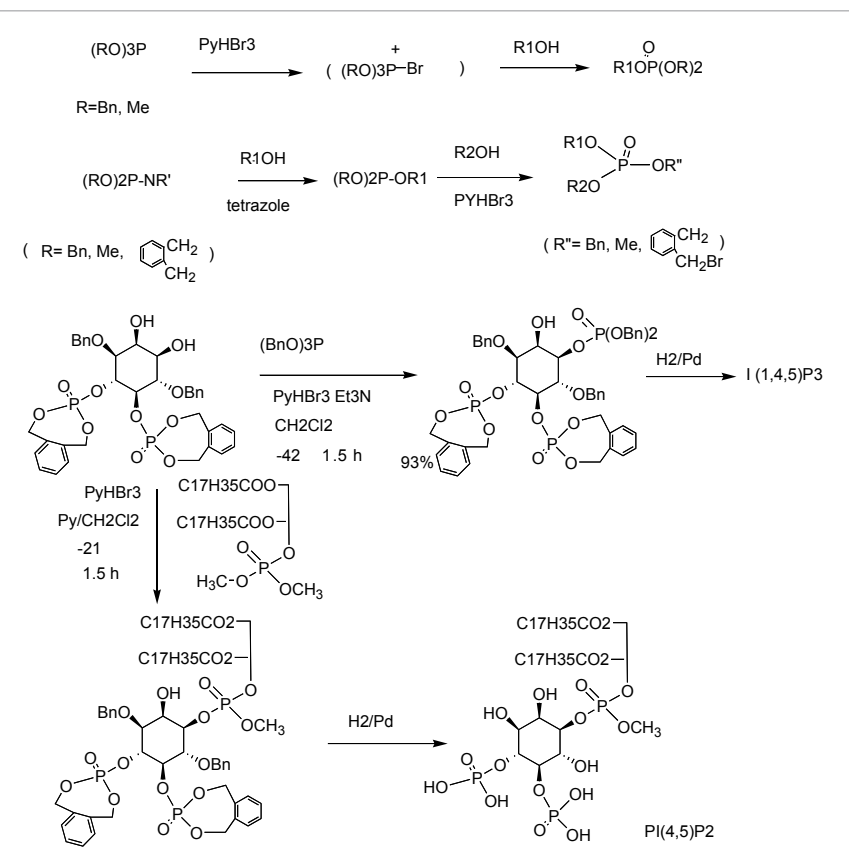

Figure 2: Phosphosphonium salt methodology for the synthesis of IPx nd PIPx.

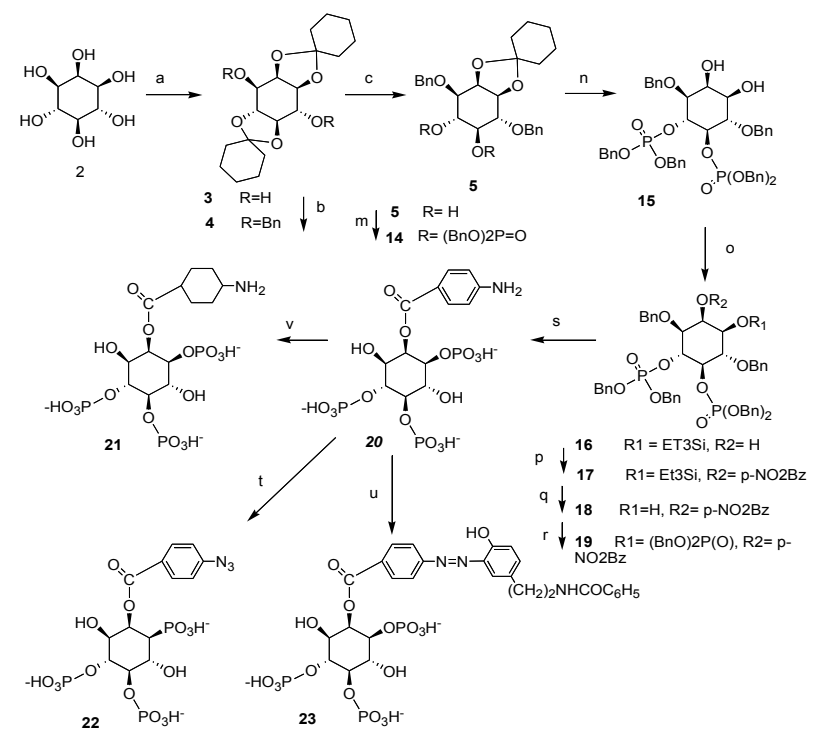

a: 1-Et-O-cyclohexane/TsOH, b: NaH/BnCl/DMF, c: ((HOCH2)2/TsOH, m: Tetrabenzyl pyrophosphate,n-BuLi

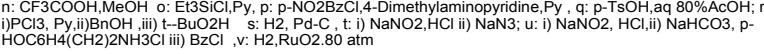

Figure 3: Preparation of ins $(1,4,5) \mathrm{P} 3$ an alogues

of nitril oxides to chiral acryloyoxy esters bearing cyclitols as auxiliaries [82].

- Asymmetric synthesis of functionalized tertially alcohols by the diastereoselective aldol reaction [83].

Preparation of $\mathrm{IPx}, \mathrm{IP}_{3}$ derivatives and $\mathrm{IP}_{3}$ Analog, and Assessment of their Activities

\section{Synthesized inositol poly phosphate [66,84-86]}

Myo-inositol

1-phosphate

$[87,88]$,

myo-inositol 1.3.4-trisphosphate [89], myo-inositol 1.4,6-trisphosphate [90], myo-inositol 1.3.4.5-tetrakisphosphate [91-93], myo-inositol 1.4,5,6-tetrakisphosphate [94], myo-inositol 2,4,5-trisphosphate [57], 1,2-cyclic-4,5-, 1,4,5- and 2,4,5-triphosphate [95], myo-inositol 1.2,5,6-tetrakisphosphate [65], 2,6-Di-O-(D- mannopyranosyl) phosphatidyl-D-myo-inositol [68], Phosphofluoridate analogs of myo-inositol 1,4,5-tris(phosphate) [55]. 4-a-D-glucopyranosyl-myoinositol [50].

\section{2-substituted $\mathrm{IP}_{3}$ analogs}

- These were synthesized as shown in Figure 3. These analogs were used for the preparation of affinity columns [96].

- Many IP ${ }_{n}$ and derivatives were prepared and their activities were measured by Prof. Hirata, Masato [96-113].

- Synthesis of $\mathrm{IP}_{3}$ having biotinyl and azidobenzoyl groups [100].

- Synthesis of 2-substituted myo-inositol 1,3,4,5-tetrakis(phosphate) and 1,3,4,5,6-pentakis(phosphateanalogues [101].

\section{Phosphofloridate analogues}

Phosphofluoridate analogs of myo-inositol 1,4,5-tris(phosphate) were prepared as shown in Figure 4 [56].

The three phosphofluoridates thus prepared had potencies for inhibiting $\left({ }^{3} \mathrm{H}\right) \mathrm{Ins}_{3}$ binding to purified Ins $\mathrm{P}_{3}$ receptor that were less than for $\operatorname{InsP}_{3}$. Two analogues 44 and 40 were found to inhibit the dephosphorylation of $\left({ }^{1} \mathrm{H}\right)$ Ins $\mathrm{P}_{3}$ by the 5-phsphatase with potencies similar to that for $\operatorname{InsP}_{3}$. Surprisingly, the inhibitory potency of 5-phosphofluoridate 44 toward 5-phosphosphatase was higher (about 20 fold) than those of $\operatorname{InsP}_{3}$ and the another fluoridates 40 and 45.

\section{Preparation of Affinity Column}

Inositol 1,4,5-trisphosphate affinity columns 24,25 were prepared from 20,21 as shown in Figure 5 to fish out $\mathrm{IP}_{3}$-binding proteins $[98,113,114]$.

\section{Isolation and Characterization of Many $\mathrm{IP}_{3}$-Binding Proteins}

The following many proteins were isolated by affinity column and characterizations were carried out $[103,111]$.

- $\mathrm{IP}_{3}$ binding protein $[102,103,113,115]$ co-work with Hirata Masato

- Phospholipase C-d1 [110,116] co-work with Hirata Masato.

- Porcine tracheal smooth muscle aldrase [109], collaboration with Carl Baron and Masato Hirata.

- 3-Kinase, 5-phosphatase [111,117] collaboration withVan Dijken

- Growth factor activating protein [112,118] collaboration with Moriya Shigeharu

- $\mathrm{IP}_{3}$ 3-kinase from porcine smooth muscle [119-121] co-work with Denborough.

- RAC-protein kinase (PKB/Akt [120] collaboration with Matsuzaki

- Expression and characterization of $\mathrm{IP}_{3}$-binding domain of phosphatidyl inositol-specific phospholipase C [122] collaboration with Yagisawa, Hitoshi.

- $\mathrm{IP}_{3}$ 3-kinase from chicken erythrocytes [123] collaboration with George Myer. 


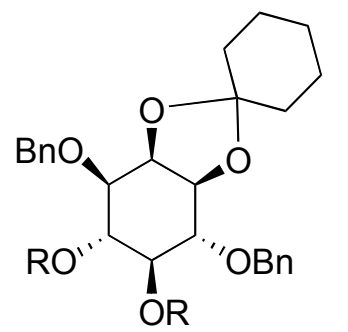<smiles>C[Hg]</smiles>

a

$5 \quad \mathrm{R} 1=\mathrm{R} 2=\mathrm{H}$

27a R1= TES, R2= H

27b $R 1=H, R 2=T E S$

b

28a R1= TES, R2= $\mathrm{P}(\mathrm{O})(\mathrm{OBn}) 2$

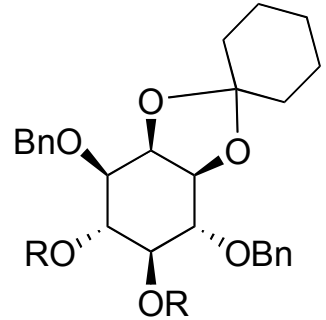

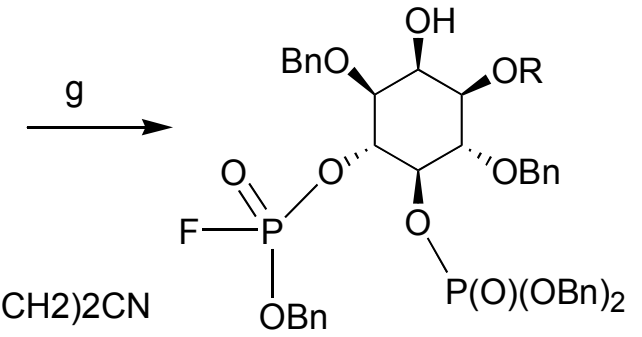

e

30a $\mathrm{R}=\mathrm{P}(\mathrm{O})(\mathrm{Bn}) \mathrm{O}(\mathrm{CH} 2) 2 \mathrm{CN}$ 31a $R=P(O)(O B n) O-$

32a $\mathrm{R}=\mathrm{P}(\mathrm{O})(\mathrm{OBn}) \mathrm{F}$

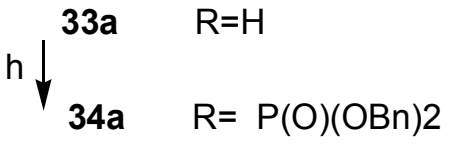

28b $R 1=P(O)(O B n) 2, R 2=T E S$

$c$

29a R1=H, R2=P(O)(OBn)2

29b $\mathrm{R} 1=\mathrm{P}(\mathrm{O})(\mathrm{OBn}) 2, \mathrm{R} 2=\mathrm{H}$<smiles>CC(C)N(C)[Po+]</smiles><smiles>CCCC</smiles><smiles>[R]O[C@H]1[C@@H](O)[C@@H](O)[C@@H](O)[C@H](O)[C@H]1O[R]</smiles>

j \} 3 5 \quad \mathrm { R } = \mathrm { P } ( \mathrm { O } ) ( \mathrm { OBn } ) 2

k

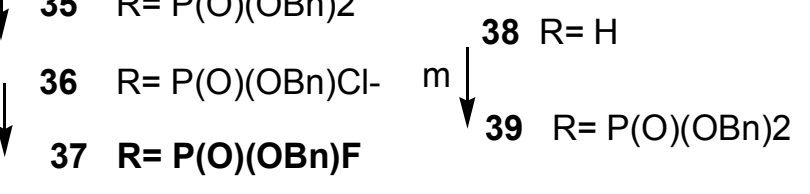

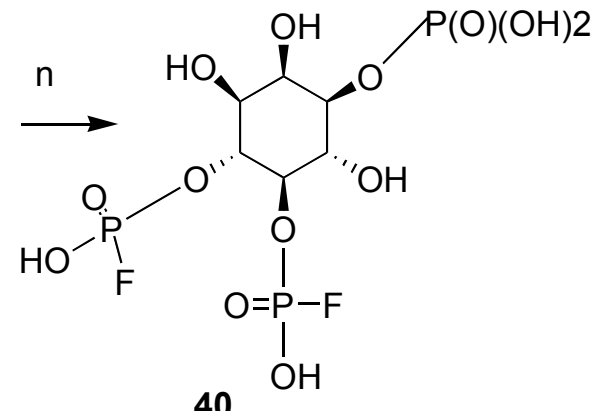

40

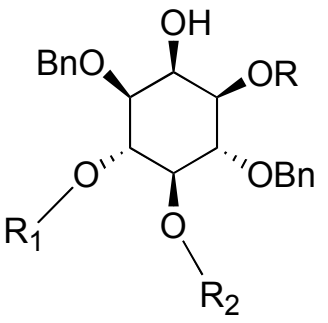<smiles>CCCC</smiles>

$42 \mathrm{R} 1-\mathrm{P}(\mathrm{O})(\mathrm{OBn}) \mathrm{O}-\mathrm{R} 2=\mathrm{R}(\mathrm{O}) \mathrm{OBn}) \mathrm{F}$

$43 \mathrm{R} 1=\mathrm{P}(\mathrm{O})(\mathrm{OBn}) \mathrm{F}$ R2=P(O)(OBn)O-<smiles>O=P(O)(O)O[C@@H]1[C@H](O)[C@@H](OP(=O)(O)O)[C@H](OP)[C@H](O)[C@H]1O</smiles>

44

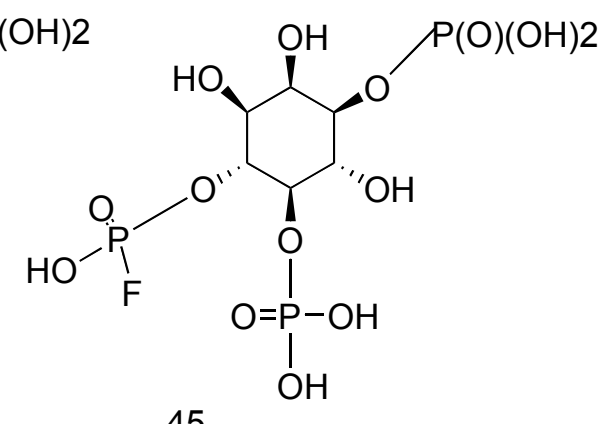

a: Et3SiCl, Py b: (BnO)2PN i-Pr2, Tetrazol then MCPBA. c: Bu4NF.3H2O, PhCO2H, THF,d: NC( $\mathrm{CH} 2) 2 \mathrm{O}(\mathrm{BnO}) \mathrm{PNiPr} 2$, Tetrazole then MCPBA, e: Et3N MeCN,rt 2h, f.: :41, Et3N, g CF3COOH, h: (BnO)3P, PyHBr3,Et3N, H2 Pd-C ,AcOH-MeOH-H2O, i: (BnO)2PN iPr2, Tetrazole then MCPBA, j: PhSH,Et3N, k:: 41, Et3N , l: CF3COOH, m: (BnO)3P,PyHBr3,Et3N n: H2, Pd-C 


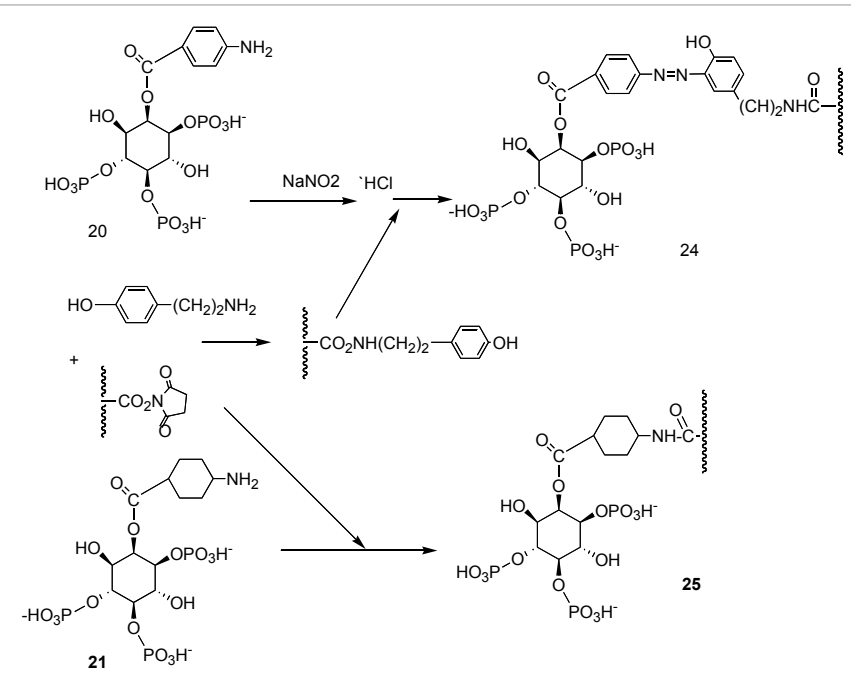

Figure 5: Preparation of IP3 affinity resin
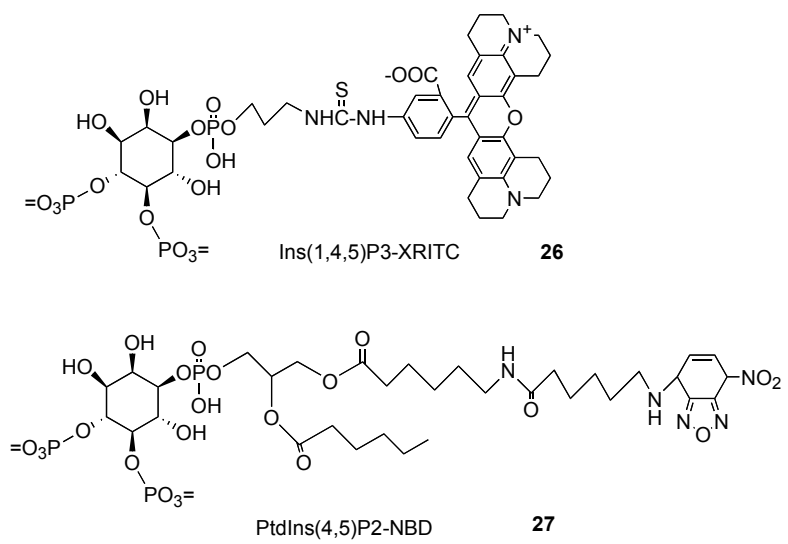

Figure 6: Fluorescent IP3 and PIP2

- Homogeneous $\mathrm{Ca}^{2+}$ Stores [124] collaboration with Inoue, Masumi

- Na+,K+- ATPase [125] collaboration with Lin, Hai

- Plasma membrane PtIns-4,5- $\mathrm{P}_{2}$ [126] collaboration with Ronald Holz

\section{Observation of Behaviors of IPx, PIPx and $\mathrm{Ca}^{2+}$ Flux in the cells}

$\mathrm{IP}_{3}$ and PIPx are charged compounds. Therefore they do not readily penetrate through cell membranes. But it becomes permeable following salt formation with amine and this is a new method to put IP or PIP into the cell [127-130].

Ozaki synthesized about 20 fluorescent $\mathrm{IP}_{3}, \mathrm{IP}_{4}, \mathrm{PIP}, \mathrm{PIP}_{2}$ containing fluorescent amines with green and red colors (Figure 6), and introduced these tagged molecules into cells. He then used fluorescent microscopy.

He observed how and how fast the IP or PIP entered into the cell and how moved and how changed, metabolized and also observed a calcium flux (time, location, concentration) in NIH 3T3 Fibloblasts, when complexes of carrier and Ptd Ins $(4,5)$ or Inos $(1,4,5) \mathrm{P}_{3}$ were added extra cellular. He took more than a thousand pictures and movies.

\section{Detection of $\mathrm{Ca}^{2+}$ Flux}

Fluoro-3 was used to measure intracellular calcium concentration. In case of $\mathrm{IP}_{3}$ complex, $\mathrm{Ca}^{2+}$ maximum peak $\left(2.5 \times 10^{-7} \mathrm{M}\right)$ was observed after 3.5 min. after addition of $\mathrm{IP}_{3}$. In case of PIPx complex, $\mathrm{Ca}^{2+}$ maximum peak $\left(4.2 \times 10^{-7} \mathrm{M}\right)$ was observed after $6.5 \mathrm{~min}$.

\section{Discovery of DAB; Regulators of $\mathrm{Ca}^{2+}$ Release and Cellular Response}

In 1997, we identified 2-aminoethyl diphenylborinate (2-APB) as being an $\mathrm{IP}_{3}$ receptor inhibiter and regulate $\mathrm{IP}_{3}$ induced calcium release $[131,132]$. This discovery rose a substantial interest and had a great impact as it gained more than 600 citations and more than 1000 studies on 2-APB have been published so far. This was supported by increasing sales of 2-APB by Sigma-Aldrich as membrane-permeable modulator of calcium release. We aimed at generate better modulator of calcium release than $2-\mathrm{APB}$.

We synthesizes several $2 \mathrm{APB}$ analogues and measured their inhibitory activities on Store Operated Calcium Entry (SOCE) and $\mathrm{IP}_{3}$ Induced Calcium Release (IICR).

We found that bis boron compound DBP 161 and DBP 163 were 10 times more effective than 2-APB [133-138] We extended these studies and synthesized 493 analogues [139,140] increasing the number of borons, changing diphenyl to diaryl, monoaryl, mono-aliphatic dialiphatic compounds, substitution of aminoethyl to amino acid derivative as well as aminoethanol to aminoethylthiol and studied the structure/activities correlation.

We found that Diphenyl (amino acidonate $\mathrm{O}, \mathrm{N}$ ) borane DAB are best compounds

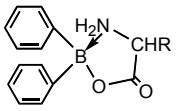

$\mathrm{DAB}$

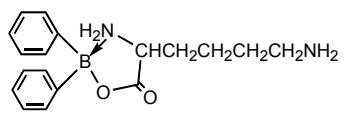

911

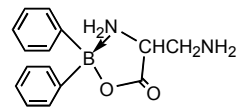

We found $[139,140]$ that compounds DAB Diphenyl (aminoacidonate $\mathrm{N}, \mathrm{O}$ )borane could regulate $\mathrm{IP}_{3}$ - induced $\mathrm{Ca}^{2+}$ release (IICR), Store-Operated $\mathrm{Ca}^{2+}$ entry (SOCE)) and could regulate cellular responses. We found that the adduct of amino acid (especially basic amino acid) and diphenyl borinic acid have strong inhibitory activity to SOCE. And some of them 919 Diphenyl (2,3-diaminopropionate O,N) borane, 911 Diphenyl (L- lysinate O,N ) borane showed 10 times strong activity than 2-APB. 2 APB is said to be a excellent lead compound for heat disease and Alzheimer's diseases as Berridge predicts [141-147].

2APB analogues presented in this study could be proven to be excellent lead compounds for many human diseases including heart disease [143,144], Alzheimer's [145-146] and Huntington disease $[148,149]$.

We found that boron compounds also can inhibit transglutaminase $\left(\mathrm{Ca}^{2+}\right.$-dependent enzyme) [130]. There are many neurodegenerative disease, including Alzheimer`s disease, Huntington `s disease [136,149]. The boron compounds were found to be effective as inhibitor of acyl protein thioesterase [150].

We looked for more effective transglutaminase inhibitors. We synthesized $250 \beta$-aminoethyl ketones and found that these compounds had strong transglutaminase inhibitory activities [151,152]. A typical compound is 5-bromo-2-thienyl-(N-t-butyl-N-benzyl)-aminoethyl ketone. 
Citation: Ozaki S (2014) Chemical Approach to Signal Transduction by Inositol Triphosphate. J Bioengineer \& Biomedical Sci 4: 133. doi: 10.4172/2155- 9538.1000133

Page 7 of 10

\section{Acknowledgement}

I would like to thank Dr. M. J. Berridge for valuable suggestions and advices.

\section{References}

1. Nishizuka $Y$ (1984) The role of protein kinase $C$ in cell surface signal transduction and tumour promotion. Nature 308: 693-698.

2. Frezza $C(2014)$ The role of mitochondria in the oncogenic signal transduction. Int J Biochem Cell Biol 48: 11-17.

3. Michell RH (1975) Inositol phospholipids and cell surface receptor function. Biochim Biophys Acta 415: 81-47.

4. Fain JN, Berridge MJ (1979) Relationship between hormonal activation of phosphatidylinositol hydrolysis, fluid secretion and calcium flux in the blowfly salivary gland. Biochem J 178: 45-58.

5. Fain JN, Berridge MJ (1979) Relationship between phosphatidylinosito synthesis and recovery of 5-hydroxytryptamine-responsive Ca2+ flux in blowfly salivary glands. Biochem J 180: 655-661.

6. Berridge MJ, Downes CP, Hanley MR (1982) Lithium amplifies agonistdependent phosphatidylinositol responses in brain and salivary glands. Biochem J 206: 587-595

7. Berridge MJ, Dawson RMC, Downes CP, Heslop JP, Irvine RF (1983) Changes in the levels of inositol phosphates after agonist-dependent hydrolysis of membrane phosphoinositides. Biochem J 212: 473-482.

8. Berridge MJ (1983) Rapid accumulation of inositol trisphosphate reveals that agonists hydrolyse polyphosphoinositides instead of phosphatidylinositol. Biochem J 212: 849-858.

9. Streb H, Irvine RF, Berridge MJ, Schulz I (1983) Release of Ca2+ from a nonmitochondrial intracellular store in pancreatic acinar cells by inositol-1,4,5trisphosphate. Nature 306: 67-69.

10. Berridge MJ, Heslop JP, Irvine RF, Brown KD (1984) Inositol trisphosphate formation and calcium mobilization in Swiss 3 T3 cells in response to plateletderived growth factor. Biochem J 222: 195-201.

11. Fein A, Payne R, Corson DW, Berridge MJ, Irvine RF (1984) Photoreceptor excitation and adaptation by inositol 1,4,5-trisphosphate. Nature 311: 157-160.

12. Brown JE, Rubin LJ, Ghalayini AJ, Tarver AP, Irvine RF, et al. (1984) A biochemical and electrophysiological examination of myo-inositol polyphosphate as a putative messenger for excitation in Limulus ventral photoreceptor cells. Nature 311: 160-163.

13. Burgess GM, Godfrey PP, McKinney JS, Berridge MJ, Irvine RF, et al. (1984) The second messenger linking receptor activation to internal $\mathrm{Ca}$ release in liver. Nature 309: 63-66.

14. Prentki M, Biden TJ, Janjic D, Irvine RF, Berridge MJ, et al. (1984) Rapid mobilization of $\mathrm{Ca} 2+$ from rat insulinoma microsomes by inositol-1,4,5trisphosphate. Nature 309: 562-564.

15. Irvine RF, Brown KD, Berridge MJ (1984) Specificity of inositol trisphosphateinduced calcium release from permeabilized Swiss-mouse 3T3 cells. Biochem J 222: 269-272.

16. Irvine RF, Letcher AJ, Heslop JP, Berridge MJ (1986) The inositol tris/ tetrakisphosphate pathway--demonstration of Ins(1,4,5)P3 3-kinase activity in animal tissues. Nature 320: 631-634.

17. Rapp PE, Berridge MJ (1981) The control of transepithelial potential oscillations in the salivary gland of Calliphora erythrocephala. J Exp Biol 93: 119-132.

18. Missiaen L, Taylor CW, Berridge MJ (1991) Spontaneous calcium release from inositol trisphosphate-sensitive calcium stores. Nature 352: 241-244.

19. Berridge MJ, Irvine RF (1984) Inositol trisphosphate, a novel second messenger in cellular signal transduction. Nature 312: 315-321.

20. Berridge MJ (1987) Inositol trisphosphate and diacylglycerol: two interacting second messengers. Annu Rev Biochem 56: 159-193.

21. Berridge MJ, Irvine RF (1989) Inositol phosphates and cell signalling. Nature 341: 197-205.

22. Berridge MJ, Downes CP, Hanley MR (1989) Neural and developmental actions of lithium: a unifying hypothesis. Cell 59: 411-419.
23. Berridge MJ (1993) Inositol trisphosphate and calcium signalling. Nature 361 315-325.

24. Bootman MD, Berridge MJ (1995) The elemental principles of calcium signaling Cell 83: 675-678.

25. Decrock E, De Bock M, Wang N, Gadicherla AK, Bol M, et al. (2013) IP3, a small molecule with a powerful message. Biochim Biophys Acta 1833: 1772 1786.

26. Shoichiro O, Yutaka W, Tomio O, Yoshihasa K, Naokazu S, et al. (1986) Total synthesis of optically active myo-inositol 1,4,5-tris(phosphate). Tetrahedron Letters 27: 3157-3160.

27. Shoichiro O, Yoshihisa K, Naokazu S, Tomio O, Yutaka W (1992) Synthesis and some properties of D-myo-inositol 1,4,5-tris(dihydrogen phosphate). Journal of the Chemical Society, Perkin Transactions 1: 729-737.

28. Falck JR, Abdali A, Wittenberger SJ (1990) Total synthesis of the 5-methylenephosphonate analogue of D-myo-inositol 1,4,5-trisphosphate. J Chem Soc, Chem Commun: 953-955.

29. http://www.sciencedirect.com/science/journal/00086215/140/1

30. Vacca JP, deSolmsJS, Huff JR, Billington DC, Baker R, et al. (1989) The total synthesis of myo-inositol polyphosphates. Tetrahedron 45: 5679-5702.

31. Ley SV, Parra M, Redgrave AJ, Sternfeld F (1990) Microbial oxidation in synthesis: preparation of myo-inositol phosphates and related cyclitol derivatives from benzene. Tetrahedron 46: 4995-5026.

32. Falck JR, Yadagiri PJ (1989) Enantiospecific synthesis of D-myo-inosito 1,4,5-trisphosphate from (-)-quinic acid. J Org Chem 54: 5851-5852.

33. http://www.sciencedirect.com/science/journal/00404039/10/59

34. Maracek JP, Prestwich GD (1989) Synthesis of D-myo-(-3 H)I(1,4,5)P3. J Labelled Comp 27: 917.

35. Prestwich GD, Marecek JF (1991) Chemical modification of inosito trisphosphate: Tritiated,fluorinated and phosphate-tetered analogues, ACS Symposium Series 463 Inositolpolyphosphate and derivatives Edit Allen B. Reitz: 3322-131.

36. Potter BVL (1991) Phosphothioate analogues of D-myo-inosito 1,4,5-Trisphosphate. ACS Symposium Series 463 Inositolpolyphosphate and derivatives Edit Allen B. Reitz: 186-201.

37. Takahiko A, Naoto T, Shoichiro O (1990) Chiral synthesis of D-myo-inosito 1-phosphate starting from L-quebrachitol. Tetrahedron Letters 31: 1433-1434.

38. Takahiko A, Hiroaki S, Shoichiro O (1991) A concise synthesis of (-)-conduritol $\mathrm{F}$ from L-quebrachitol via AICI3-n-Bu4NI mediated demethylation. Tetrahedron Letters 32: 5593-5696.

39. Takahiko A, Masatoshi O, Hiroaki S, Shoichiro O (1991) Total synthesis of cyclophellitol from L-quebrachitol. Synlett 11: 831-832.

40. Takahiko A, Hiroaki S, Masatoshi O, Tadashi O, Shoichiro O (1993) Synthesis of (-)-conduritol $\mathrm{F},(+)$-conduritol B, cyclophellitol from L-quebrachitol. Bulletin of the Chemical Society of Japan 66: 3760-3767.

41. Takahiko A, Hiroyuki N, Takaaki K, Shoichiro O (1994) Stereodivergen synthesis of optically active a-hydroxy acids via diastereoselective reduction of a-keto esters derived from L-quebrachitol. Bulletin of the Chemical Society of Japan 67: 180-188.

42. Yutaka W, Motohiro M, Shoichiro O (1987) Synthesis of optically active inosito derivatives starting from D-glucurono-6,3-lactone. Chemistry Letters 1: 123126.

43. Lei L, Yutaka W, Takahiko A, Shoichiro O (1992) A new efficient method for resolution of myo-inositol derivatives by enzyme catalyzed regio- and enantioselective esterification in organic solvent. Tetrahedron Letters 33: 1911 1914.

44. Ling L, Li X, Watanabe Y, Akiyama T, Ozaki S (1993) Enzymatic resolution of racemic 1,2:5,6-di-O-cyclohexylidene and 1,2:3,4-di-O-cyclohexylidene-myoinositol. Bioorg Med Chem 1: 155-159.

45. Lei L, Shoichiro O (1993) Enzyme aided synthesis of D-myo-inosito 1,4,5-trisphospgate. Tetrahedron Letter 34: 2501-2504.

46. Ling L, Ozaki S (1994) A chemoenzymatic synthesis of D-myo-inosito 1,4,5-trisphosphate. Carbohydr Res 256: 49-58. 
47. Lei L, Shoichiro O (1995) Enzymic resolution of the sterically hindered myoinositol derivative. Bulletin of the Chemical Society of Japan 68: 1200-1205.

48. Shoichiro O, Lei L (1997) Chemoenzymatic Synthesis of Optically Active myoinositol Polyphosphate. Carbohydrates in Drug Design.

49. Shoichiro O, Kayoko Y, Takako K, Takahiro M, Mitsuaki E, et al. (1995) Enzyme aided regioselective acylation of nucleosides. Nucleosides \& Nucleotides 14 401-104.

50. Yutaka W, Akinori O, Yasushi S, Shoichiro O (1990) Easy access of optically active myo-inositol derivatives by enantioselective acylation using a tartaric acid monoester. Tetrahedron Letters 31: 2613-2616.

51. Yutaka W, Tadashi O, Takashi Y, Shoichiro O (1996) Synthetic strategies based on phosphite chemistry for inositol phosphates and phospholipids. Phosphorus, Sulfur and Silicon and the Related Elements: 109-110.

52. Yutaka W, Hiroyuki N, Motonobu B, Shoichiro O (1987) An efficient method for polyphosphorylation of inositol derivatives. Tetrahedron Letters 28: 4179-4180.

53. Yutaka W, Yasunobu K, Katsumi E, Shoichiro O (1990) An efficient phosphorylation method using a new phosphitylating agent, 2-(diethylamino)1,3,2-benzodioxaphosphepane. Tetrahedron Letters 31: 255-256.

54. Yutaka W, Yasunobu K, Shoichiro O (1992) Utilization o-xylylene N,Ndiethylphosphoamidite for the synthssis of phosphoric diesters. Tetrahedron Letters 33: 133-136.

55. Yutaka W, Nobuyuki H, Shoichiro O (1988) Dibenzyl phosphorofluoridate, a new phosphorylating agent. Tetrahedron Letters 29: 5763-5764.

56. Yutaka W, Shinsuke S, Shoichiro O, Masato H (1996) Synthesis of phosphorofluoridate analogs of myo-inositol 1,4,5-tris(phosphate) and their biological activity. Chemical Communications (Cambridge) 15: 1815-1816.

57. Yutaka W, Tomio O, Naokazu S, Shoichiro O (1987) Stepwise phosphorylation of vicinal diol and sterically hindered alcohol directed toward D-myo-inositol 2,4,5-trisphosphate. Tetrahedron Letters 28: 2607-2610.

58. Yutaka W, Shinji I, Takashi Y, Shoichiro O (1995) Phosphorothioate synthesis based on the redox reaction of phosphite with tellurium(IV) chloride. Synthesis 10: $1243-1244$

59. Yutaka W, Eiji I, Masanao J, Shoichiro O (1993) Phosphonium salt methodology for the synthesis of phosphoric monoesters and diesters and its application to selective phosphorylation. Tetrahedron Letters 34: 497-500.

60. Shoichiro O, Yutaka W, Takehiro M, Yuichi H, Tomio O, et al. (1998) Synthesis of phosphatidyl-myo-inositol polyphosphates and derivatives. ACS Symposium Series 718 Phosphoinositides, Edit Karol Bruzik: 212-221.

61. Yutaka W, Shinichi M, Shoichiro O (1992) $1 \mathrm{H}-$-Tetrazole catalyzed reactions of trialkyl phosphites: observation of a five-membered cyclic hydrophosphorane intermediate during the transesterification. Journal of the Chemical Society, Perkin Transactions 1: Organic and Bio-Organic Chemistry 15: 1879-1880.

62. Yutaka W, Takashi Y, Taroh I, Shoichiro O (1994) Utilization of oxidizing character of $\mathrm{TeCl} 4$ in the reaction with trialkyl phosphite. A novel redox phosphorylation. Chemistry Letters 10: 1881-1884.

63. Yutaka W, Hajimu H, Shoichiro O (1994) Synthesis of a phosphatidylinositol 3,4,5-trisphosphate. Tetrahedron Letters 35: 123-124.

64. YutakaW, Masaya T, Shoichiro O (1995) Synthesis of 1D-distearoylphosphatidylmyo-inositol 3,4,5-tris(dihydrogen phosphate). Tetrahedron 51: 8969-8976

65. Shoichiro O, Xiang-Zheng K, Yutaka W, Tomio O (1998) Synthesis of unsaturated phosphatidyl inositol-3,4,5-trisphosphate. Chinese Journal of Chemistry 16: 51-57.

66. Shoichiro O, Watanabe Y (1991) Synthesis of Inositol Polyphosphate and Their Derivatives. ACS Symposium Series 463 Inositolpolyphosphate and derivatives Edit Allen B Reitz: 41-64

67. Yutaka W, Chikara N, Shoichiro O, Michikatsu S, Kyoko K (1993) Absolute configuration of 4-a -D-glucopyranosyl-myo-inositol, enzymic transglycosylation product. Journal of Carbohydrate Chemistry 12: 685-692.

68. Yutaka W, Takashi Y, Shoichiro O (1996) Synthesis of 2,6-Di-O-(a -D-mannopyranosyl)phosphatidyl-D-myo-inositol. Tetrahedron 53: 903-918.

69. Yutaka W, Motohiro M, Takao M, Shoichiro O (1989) Highly efficient protection by the tetraisopropyldisiloxane-1,3-diyl group in the synthesis of myo-inositol phosphates as inositol 1,3,4,6-tetrakisphosphate. Journal of the Chemical
Society, Chemical Communications 8: 482-483.

70. Yutaka W, Masanori I, Shoichiro O (1994) Proximately assisted and chemoselectively cleavable protecting groups for alcohols, 2-[2-(arylmethyloxy) ethyl]benzoic esters. Chemistry Letters 11: 2163-2166.

71. Takahiko A, Naoto T, Hiroaki S, Shoichiro O (1990) Anchimerically assisted demethylation of methyl ethers in inositol derivatives with an aluminum chloridesodium iodide system. Chemistry Letters 10: 1881-1884.

72. Takahiko A, Hajimu H, Shoichirio O (1992) Aluminium chloride-N,Ndimethylaniline: anovel benzyl and allyl ether cleavage reagent. Bulletin of the Chemical Society of Japan 65: 1932-1938.

73. Takahiko A, Hiroaki S, Shoichiro O (1992) Trimethylsilyl chroride-tin(II)chlorideanisole: a novel p-methoxybenzyl ether cleavage reagent. Synlett 5: 415-416.

74. Takahiko A, Hiroyuki N, Keiichiro I, Shoichiro O (1992) Diastereoselective addition of organometallics to a-keto esters bearing chiro-inositol derivatives as chiral auxiliaries. Chemistry Letters 3: 447-450.

75. Tadahiki A, Hiruyuki N, Shoichiro O (1991) Diastereoselective reduction of a-ketoesters bearing chiri-nositol derivatives as chirl auxiliaries. Tetrahedron Letters 32: 1335-1338.

76. Yutaka W, Takahiro F, Shoichiro O (1992) A novel deacylation method using Grignard reagent without affecting the neighboring base-sensitive functional groups. Journal of the Chemical Society, Chemical Communications 9: 681 683.

77. Ozaki S, Uemura A, Konishi T, Yamashita K, Maekawa T, et al. (1993) Enzyme aided regio-selective acylation and deacylation of nucleosides. Nucleic Acids Symp Ser: 53-54.

78. Yutaka W, Chikara N, Shoichiro O (1993) Glycosidation based on phosphite chemistry. Synlett 2: 115-116.

79. Yutaka W, Chikara N, Takashi Y, Shoichiro O (1994) Glycosylation using glycosyl phosphite as a glycosyl donor. Tetrahedron 50: 6523-6536.

80. Van Dijken P, Lammers AA, Ozaki S, Potter BV, Erneux C, et al. (1994) Phosphorylation of inositol 1,4,5-trisphosphate analogues by 3-kinase and dephosphorylation of inositol 1,3,4,5-tetrakisphosphate analogues by 5-phosphatase. Eur J Biochem 226: 561-566.

81. Akiyama T, Yasusa T, Ishikawa K, Ozaki S (1994) Asymmetric synthesis of tetrahydrofurans by diastereoselective [3+2]-cycloaddition of allylsilanes with a -keto esters bearing an optically active cyclitol as a chiral auxiliary. Tetrahedron Letters 35: 8401-8404.

82. Akiyama T, Okada K, Ozaki S (1992) The preparation of optically active D 2-isoxazolines via addition of nitrile oxides to chiral acryloyl esters bearing cyclitols as auxiliaries. Tetrahedron Letters 33: 5763-5766.

83. Akiyama T, Ishikawa K, Ozaki S (1994) Asymmetric synthesis of functionalized tertiary alcohols by diastereoselective aldol reaction of silyl enol ether and ketene silyl acetal with a -keto esters bearing an optically active cyclitol as a chiral auxiliary. Synlett 4: 275-276.

84. Ozaki S, Watanabe Y, Hirata M, Awaya A (1991) Preparation of inosito polyphosphate derivatives for control of the calcium ion-participating metabolic steps. PCT Int. Appl: 139.

85. Ozaki S, Watanabe Y (1989) Synthesis of inositol polyphosphates. Yuki Gose Kagaku Kyokaishi 47: 363-373.

86. Watanabe Y, Ozaki S (1992) Organic chemical approach to inosito phospholipid-associated signal transduction. Farumashia 28: 598-602.

87. Ozaki S, Akiyama T, Takechi N, Kageyama K, Machida M (1991) Preparation of d-myoinositol 1-phosphate. Ger Offen 8.

88. Akiyama T, Takechi N, Ozaki S, Shiota K (1992) A chiral synthesis of D-myoinositol 1-phosphate starting from L-quebrachitol. Bulletin of the Chemical Society of Japan 65: 366-372.

89. Ozaki S, Kohno M, Nakahira H, Bunya M, Watanabe $Y$ (1988) Synthesis of optically active myo-inositol 1,3,4-trisphosphate. Chemistry Letters: 77-80.

90. Watanabe Y, Ogasawara T, Ozaki S, Hirata M (1994) Synthesis of myoinositol 1,4,6-trisphosphate, an analog of myo-inositol 1,4,5-trisphosphate. Carbohydrate Research 258: 87-92.

91. Ozaki S, Kondo Y, Nakahira H, Yamaoka S, Watanabe $Y$ (1987) Synthesis of D-myo-inositol 1,3,4,5-tetrakisphosphate. Tetrahedron Letters 28: 4691-4694. 
92. Watanabe $Y$, Shinohara T, Fujimoto T, Ozaki S (1990) A short step and practical synthesis of myo-inositol 1,3,4,5-tetrakisphosphate. Chemical \& Pharmaceutical Bulletin 38: 562-563.

93. Watanabe $\mathrm{Y}$, Fujimoto T, Shinohara T, Ozaki S (1991) A short step synthesis of optically active myo-inositol 1,3,4,5-tetrakis(phosphate) and myo-inositol 1,4,5-tris(phosphate) from 1,3,5-tri-O-benzoyl-myo-inositol. Journal of the Chemical Society, Chemical Communications 6: 428-429.

94. Ozaki S, Ling L, Ogasawara T, Watanabe Y, Hirata M (1994) A convenient chemoenzymatic synthesis of D-and L-myo-inositol 1,4,5,6-tetrakisphosphate. Carbohydr Res 259: 307-310.

95. Watanabe Y, Ogasawara T, Nakahira H, Matsuki T, Ozaki S (1988) A versatile intermediate, D-4,5-bis(dibenzyl phosphoryl)-myo-inositol derivative, for synthesis of inositol phosphates. Synthesis of 1,2-cyclic-4,5-, 1,4,5-, and 2,4,5-trisphosphate. Tetrahedron Letters 29: 5259-5262.

96. Ozaki S, Watanabe Y, Ogasawara T, Hirata M, Kanematsu T (1992) Synthesis and biological properties of 2-substituted myo-inositol 1,4,5-trisphosphate analogues directed toward affinity chromatography and photoaffinity labeling Carbohydr Res 234: 189-206.

97. Hirata M, Watanabe Y, Ishimatsu T, Ikebe T, Kimura Y, et al. (1989) Synthetic inositol trisphosphate analogs and their effects on phosphatase, kinase, and the release of Ca2+. J Biol Chem 264: 20303-20308.

98. Hirata M, Watanabe Y, Ishimatsu T, Yanaga F, Koga T, et al. (1990) Inositol 1,4,5-trisphosphate affinity chromatography. Biochem Biophys Res Commun 168: $379-386$.

99. Hirata M, Yanaga F, Koga T, Ogasawara T, Watanabe Y, et al. (1990) Stereospecific recognition of inositol 1,4,5-trisphosphate analogs by the phosphatase, kinase, and binding proteins. J Biol Chem 265: 8404-8407.

100. Hirata M, Kimura Y, Ishimatsu T, Yanaga F, Shuto T, et al. (1991) Synthetic inositol 1,3,4,5-tetrakisphosphate analogues. Biochem J 276 : 333-336.

101. Kimura Y, Kanematsu T, Watanabe Y, Ozaki S, Koga T, et al. (1991) Synthetic inositol 1,3,4,5-tetrakisphosphate analogs and their effect on the binding to microsomal fraction of rat cerebellum. Biochimica et Biophysica Acta, Biomembranes 1069: 218-222.

102. Kanematsu $T$, Takeya $\mathrm{H}$, Watanabe $\mathrm{Y}$, Ozaki S, Yoshida M et al (1992) Putative inositol 1,4,5-trisphosphate binding proteins in rat brain cytosol. J Biol Chem 267: 6518-6525.

103. Kamata H, Hirata M, Ozaki S, Kusaka I, Kagawa Y, et al. (1992) Partia purification and reconstitution of inositol 1,4,5-trisphosphate receptor/Ca2+ channel of bovine liver microsomes. J Biochem 111: 546-552.

104. Hirata M, Watanabe Y, Yoshida M, Koga T, Ozaki S (1993) Roles for hydroxyl groups of D-myo-inositol 1,4,5-trisphosphate in the recognition by its receptor and metabolic enzymes. J Biol Chem 268: 19260-19266.

105. Hashii M, Hirata M, Ozaki S, Nozawa Y, Higashida H (1994) Ca2+ influx evoked by inositol-3,4,5,6-tetrakisphosphate in ras-transformed $\mathrm{NIH} / 3 \mathrm{~T} 3$ fibroblasts. FEBS Lett 340: 276-280.

106. Hirata M, Narumoto N, Watanabe Y, Kanematsu T, Koga T, et al. (1994) DL-myo-inositol 1,2,4,5-tetrakisphosphate, a potent analog of D-myo-inositol 1,4,5-trisphosphate. Mol Pharmacol 45: 271-276.

107. Hashii M, Hirata M, Ozaki S, Nozawa Y, Higashida H (1994) Ca2+ influx gated by inositol-3,4,5,6-tetrakisphosphate in NIH/3T3 fibroblasts. Biochem Biophys Res Commun 200: 1300-1306.

108. Hirata M, Watanabe Y, Kanematsu T, Ozaki S, Koga T (1995) D-myo-inosito 1,4,5-trisphosphate analogues substituted at the 3-hydroxyl group. Biochim Biophys Acta 1244: 404-410.

109. Baron CB, Ozaki S, Watanabe Y, Hirata M, LaBelle EF, et al. (1995) Inosito 1,4,5-trisphosphate binding to porcine tracheal smooth muscle aldolase. J Biol Chem 270: 20459-20465.

110. Kanematsu T, Misumi $Y$, Watanabe $Y$, Ozaki S, et al. (1996) A new inositol 1,4,5-trisphosphate binding protein similar to phospholipase C-d 1. Biochemical Journal 313: 319-325.

111. Watanabe Y, Hirata M, Ogasawara T, Koga T, Ozaki S (1991) Synthesis and characterization of a photoaffinity probe possessing biotinyl and azidobenzoy moieties for IP3-affiniated protein. Bioorganic \& Medicinal Chemistry Letters 1: $399-402$
112. Ozaki S, Koga $Y$, Ling $L$, Watanabe $Y$, Kimura $Y$, et al. (1994) Synthesis of 2-substituted myo-inositol 1,3,4,5-tetrakis(phosphate) and 1,3,4,5,6-pentakis(phosphate) analogs. Bulletin of the Chemical Society of Japan 67: 1058-1063.

113. Ozaki S, Watanabe Y, Hirata M, Ogasawara Y, Kanematsu T, et al. (1993) Inositol 1,4,5-triphosphate Affinity Chromatography. Fishing out Ins $(1,4,5)$ P3-recognizable Protein. Drug Design for neuroscience Edit Alan Kozikowsk Raven Press: 417-434.

114. Ozaki S, Kong $X$, Watanabe $Y$, Ogasawara $T$ (1997) Synthesis of affinity column of phosphatidylinositol-3,4-diphosphate. Chinese Journal of Chemistry 15: 556-561.

115. Yagisawa H, Hirata M, Kanematsu T, Watanabe Y, Ozaki S, et al. (1994) Expression and characterization of an inositol 1,4,5-trisphosphate binding domain of phosphatidylinositol-specific phospholipase C-delta 1. J Biol Chem 269: 20179-20188.

116. Yoshida M, Kanematsu T, Watanabe Y, Koga T, Ozaki S, et al. (1994) D-myo-inositol 1,4,5-trisphosphate-binding proteins in rat brain membranes. J Biochem 115: 973-980.

117. Hirata M, Kanematsu T, Sakuma K, Koga T, Watanabe Y, et al. (1994) D-myo-Inositol 1,4,5-trisphosphate binding domain of phospholipase C-d 1 . Biochemical and Biophysical Research Communications 205: 1563-1571.

118. Moriya S, Kazlauskas A, Akimoto K, Hirai S, Mizuno K, et al. (1996) Plateletderived growth factor activates protein kinase $\mathrm{C}$ epsilon through redundant and independent signaling pathways involving phospholipase $\mathrm{C}$ gamma or phosphatidylinositol 3-kinase. Proc Natl Acad Sci U S A 93: 151-155.

119. Hogan SP, Foster PS, Hansbro PM, Ozaki S, Denborough MA (1994) Detection and partial purification of inositol 1,4,5-trisphosphate 3-kinase from porcine skeletal muscle. Cell Signal 6: 233-243.

120. Hidenori M, Hiroaki K, Motonari T, Yoshitaka O, Tadaomi T, et al. (1996) Isolation of the active form of RAC-protein kinase (PKB/Akt) from transfected COS-7 cells treated with heat shock stress and effects of phosphatidylinosito 3,4,5-trisphosphate and phosphatidylinositol 4,5-bisphosphate on its enzyme activity. FEBS Letters 396: 305-308.

121. Foster PS, Hogan SP, Hansbro PM, O'Brien R, Potter BV, et al. (1994) The metabolism of D-myo-inositol 1,4,5-trisphosphate and D-myo-inosito 1,3,4,5-tetrakisphosphate by porcine skeletal muscle. Eur J Biochem 222 955-964.

122. Yagisawa H, Hirata M, Kanematsu T, Watanabe Y, Ozaki S, et al. (1994) Expression and characterization of an inositol 1,4,5-trisphosphate binding domain of phosphatidylinositol-specific phospholipase C-d 1. Journal of Biological Chemistry 269: 79-88.

123. Bertsch U, Haefs M, Moller M, Deschermeier C, Fanick W, et al (1999) A novel A-isoform-like inositol 1,4,5-trisphosphate 3-kinase from chicken erythrocytes exhibits alternative splicing and conservation of intron positions between vertebrates and invertebrates. Gene 228: 61-71.

124. Inoue M, Sakamoto Y, Fujishiro N, Imanaga I, Ozaki S, et al. (2003) Homogeneous $\mathrm{Ca} 2+$ stores in rat adrenal chromaffin cells. Cell Calcium 33 19-26.

125. Lin H, Ozaki S, Fujishiro N, Takeda K, Imanaga I, et al. (2005) Subunit composition and role of $\mathrm{Na}+\mathrm{K}+-$ ATPases in adrenal chromaffin cells. J Physiol 564: 161-172.

126. Ronald WH, Michael DH, Scott DS, Stephen KF, Balla T, et al. (2000) A pleckstrin homology domain specific for phosphatidylinositol 4,5-bisphosphate (Ptdlns-4,5-P2) and fused to green fluorescent protein identifies plasma membrane Ptdlns-4,5-P2 as being important in exocytosis. Journal of Biological Chemistry 275: 17878-17885

127. Ozaki S, Wald D, Shope BD, Chen CJ, Jian P, et al. (2000) Intracellular delivery of phosphoinositides and inositol phosphates using polyamine carriers. Proceedings of the National Academy of Sciences of the United States of America 97: 11286-11291.

128. Prestwich GD, Chen R, Feng L, Ozaki S, Ferguson CG, et al. (2002) In situ detection of phospholipid and phosphoinositide metabolism. Adv Enzyme Regul 42: 19-38.

129. Dewald DB, Ozaki S, Malaviya S, Shope JC, Manabe K, et al. (2005) Cellular calcium mobilization in response to phosphoinositide delivery. Cell Calcium 38: $59-72$. 
Citation: Ozaki S (2014) Chemical Approach to Signal Transduction by Inositol Triphosphate. J Bioengineer \& Biomedical Sci 4: 133. doi: 10.4172/2155- 9538.1000133

130. Ozaki S, DeWald DB, Shope JC, Chen J, Prestwich GD (2000) Intracellular delivery of phosphoinositides and inositol phosphates using polyamine carriers. Proc Natl Acad Sci U S A 97: 11286-11291.

131. Maruyama T, Kanaji T, Nakade S, Kanno T, Mikoshiba K (1997) 2APB 2-aminoethoxydiphenyl borate, a membrane-penetrable modulator of Ins(1,4,5)P3-induced Ca2+ release. J Biochem 122: 498-505.

132. Iwasaki H, Mori Y, Hara Y, Uchida K, Zhou H, et al. (2001) 2-Aminoethoxydiphenyl borate (2-APB) inhibits capacitative calcium entry independently of the function of inositol 1,4,5-trisphosphate receptors. Receptors Channels 7: 429-439.

133. Zhou H, Iwasaki H, Nakamura T, Nakamura K, Maruyama T, et al. (2007) 2-Aminoethyl diphenylborinate analogues: selective inhibition for storeoperated Ca2+ entry. Biochem Biophys Res Commun 352: 277-282.

134. Mikoshiba K, Ozaki S, Suzuki A, Nakamura T (2007) Preparation of bisboron compounds controlling calcium concentration in cells. PCT Int Appl 118.

135. Mikoshiba K, Ozaki S, Ebii E (2009) Preparation of phenylborinic acid, poly(arylhydroxyborane), and their esters as intracellular calcium concentration regulators. Jpn Kokai Tokkyo Koho 138.

136. Mikoshiba K, Nukina N, Ozaki S, Hamada K, Goto J, et al. (2010) Preparation of phenylboron compounds as polyglutamine aggregation inhibitor.

137. Goto J, Suzuki AZ, Ozaki S, Matsumoto N, Nakamura T, et al. (2010) Two novel 2-aminoethyl diphenylborinate (2-APB) analogues differentially activate and inhibit store-operated $\mathrm{Ca}(2+)$ entry via STIM proteins. Cell Calcium 47: $1-10$.

138. Suzuki AZ, Ozaki S, Goto J, Mikoshiba K (2010) Synthesis of bisboron compounds and their strong inhibitory activity on store-operated calcium entry. Bioorganic \& Medicinal Chemistry Letters 20: 1395-1398.

139. Ozaki S, Suzuki AZ, Bauer PO, Ebisui E, Mikoshiba K (2013) 2-Aminoethyl diphenylborinate (2-APB) analogues: regulation of $\mathrm{Ca} 2+$ signaling. Biochem Biophys Res Commun 441: 286-290.

140. Ozaki S (2014) 2-Aminoethyl diphenylborinate (2APB) analogues:part 2. regulators of $\mathrm{Ca} 2+$ release and consequent cellular processes. Archives of Physiology 1: 1-6.
141. Mackenzie L, Bootman MD, Berridge MJ, Lipp P (2001) Predetermined recruitment of calcium release sites underlies excitation-contraction coupling in rat atrial myocytes. J Physiol 530: 417-429.

142. Lipp P, Laine M, Tovey SC, Burrell KM, Berridge MJ, et al. (2000) Functional InsP3 receptors that may modulate excitation-contraction coupling in the heart. Curr Biol 10: 939-942.

143. Mackenzie L, Bootman MD, Laine M, Berridge MJ, Thuring J, et al. (2002 The role of inositol 1,4,5-trisphosphate receptors in $\mathrm{Ca}(2+)$ signalling and the generation of arrhythmias in rat atrial myocytes. J Physiol 541: 395-409.

144. Proven A, Roderick HL, Conway SJ, Berridge MJ, Horton JK, et al (2006) Inositol 1,4,5-trisphosphate supports the arrhythmogenic action of endothelin-1 on ventricular cardiac myocytes. J Cell Sci 119: 3363-3375.

145. Berridge MJ (2010) Calcium hypothesis of Alzheimer's disease. Pflugers Arch 459: 441-449.

146. Berridge MJ (2011) Calcium signalling and Alzheimer's disease. Neurochem Res 36: 1149-1156.

147. Chen R, Valencia I, Zhong F, McColl KS, Roderick HL, et al. (2004) Bcl-2 functionally interacts with inositol 1,4,5-trisphosphate receptors to regulate calcium release from the ER in response to inositol 1,4,5-trisphosphate. J Cell Biol 166: 193-203.

148. Berridge MJ (2013) Dysregulation of neural calcium signaling in Alzheimer disease, bipolar disorder and schizophrenia. Prion 7: 2-13.

149. Bauer OP, Hudec R, Ozaki S, Okuno M, Ebisui E, et al. (2011) Genetic ablation and chemical inhibition of IP3R1 reduce mutant Huntington aggregation. Biochem Biophys Res Commun 416: 13-17.

150. Zimmermann TJ, Bürger M, Tashiro E, Kondoh Y, Martinez NE, et al. (2013) Boron-based inhibitors of acyl protein thioesterases 1 and 2. Chembiochem 14: $115-122$

151. Ozaki S, Ebisui E, Hamada K, Goto J, Suzuki AZ, et al. (2010) Potent transglutaminase inhibitors, aryl beta-aminoethyl ketones. Bioorg Med Chem Lett 20: 1141-1144.

152. Ozaki S, Ebisui E, Hamada K, Suzuki AZ, Terauchi A, et al. (2011) Potent transglutaminase inhibitors, Dithioß-aminoethyl ketones. Bioorganic \& Medicinal Chemistry Letters 21: 377-379. 